\title{
Article
}

\section{Settling of Copper Phases in Lime Modified Iron Silicate Slag}

\author{
Jenny Isaksson ${ }^{1, *(\mathbb{D}}$, Tommy Vikström ${ }^{2}{ }^{\mathbb{D}}$, Andreas Lennartsson ${ }^{1}{ }^{(\mathbb{C}}$, Anton Andersson ${ }^{1}$ and Caisa Samuelsson ${ }^{1}$ \\ 1 Department of Civil, Environmental and Natural Resources Engineering, Luleå University of Technology, \\ 97187 Luleå, Sweden; andreas.lennartsson@1tu.se (A.L.); anton.andersson@ltu.se (A.A.); \\ caisa.samuelsson@ltu.se (C.S.) \\ 2 Process Development, Boliden Rönnskär, Rönnskärsverken, 93281 Skelleftehamn, Sweden; \\ tommy.vikstrom@boliden.com \\ * Correspondence: jenny.isaksson@ltu.se; Tel.: +46-738-253-160
}

Citation: Isaksson, J.; Vikström, T.; Lennartsson, A.; Andersson, A.; Samuelsson, C. Settling of Copper Phases in Lime Modified Iron Silicate Slag. Metals 2021, 11, 1098. https:// doi.org/10.3390/met11071098

Academic Editor: Fernando Castro

Received: 26 May 2021

Accepted: 7 July 2021

Published: 10 July 2021

Publisher's Note: MDPI stays neutral with regard to jurisdictional claims in published maps and institutional affiliations.

Copyright: (c) 2021 by the authors. Licensee MDPI, Basel, Switzerland. This article is an open access article distributed under the terms and conditions of the Creative Commons Attribution (CC BY) license (https:// creativecommons.org/licenses/by/ $4.0 /)$.

\begin{abstract}
Copper in discarded slag decreases the profits and copper recovery during the pyrometallurgical extraction processes. The copper losses to slag can be reduced by using a settling furnace, in which mechanically entrained copper droplets separate from the slag under the action of gravity. The settling rate of entrained droplets can be increased by modifying the slag composition and, thus, the slag properties, which are known to influence the settling rate. The knowledge of industrial $\mathrm{CaO}$ slag modification in a reduced iron silicate slag with a $\mathrm{Fe} / \mathrm{SiO}_{2}$ ratio close to unity is limited. An industrial trial was thus conducted in an electric settling furnace, where the slag had been pretreated in a fuming furnace, to investigate the effect of $\mathrm{CaO}$ slag modification on the final slag copper content. Slag samples were collected from the ingoing and outgoing slag and from within the furnace of batches modified with $\mathrm{CaO}$ up to about $16 \mathrm{wt} \%$. The trial was evaluated by comparing the final slag copper content and the copper recovery in the settling furnace. The results indicate that the settling becomes more efficient with the $\mathrm{CaO}$ modification as the final slag copper content decreased with increasing $\mathrm{CaO}$ content.
\end{abstract}

Keywords: slag modification; electric settling furnace; copper losses; $\mathrm{CaO}$; industrial trial; slag properties; matte; speiss; fayalite slag; slag cleaning

\section{Introduction}

Copper losses to discarded slag are one limitation of the copper recovery in pyrometallurgical extraction of this metal. Copper is in the form of chemically dissolved and mechanically entrained copper in the molten slag phase [1,2]. The mechanically entrained copper droplets can be recovered via slag cleaning, where the entrained droplets separate from the slag under the action of gravity. At the Boliden Rönnskär smelter in the north of Sweden, one of the slag cleaning routes includes a fuming furnace followed by an electric settling furnace. The settling rate of the entrained copper-containing droplets is dependent on slag properties, which can be modified for increased settling rate, which would result in decreased copper losses to slag and enhance the recovery. Therefore, the investigation of industrial slag modification and the influence on copper losses is a task of high practical significance.

The slag in the settling furnace at the Boliden Rönnskär smelter originates from a sulfidic copper concentrate smelted in an electric smelting furnace (ESF) together with fluxes, slag returns, and secondary material. The generated slag is sent to a fuming furnace for zinc extraction by reduction and vaporization, described in more detail by Lotfian et al. [3]. The remaining slag is tapped to the settling furnace, where entrained copper phases can separate from the slag under the action of gravity. The mechanically entrained copper is in the form of matte (copper-iron-sulfide) and speiss (rich in copper and also contains arsenic, antimony, tin, and nickel) [4]. The settled copper is tapped from the settling furnace and can be recycled to the smelter. The slag remaining after a given 
settling time in the furnace is water granulated [5] at a production rate of $\sim 250,000$ tons per year, and commonly used as construction material and for sandblasting, for example. The utilization of the granulated slag enhances the circular economy for the smelter and decreases the extent of landfilling and the use of natural resources.

Slag generated in the smelting stage during pyrometallurgical production of copper often has the main components iron oxide and silica $\left(\mathrm{FeO}\right.$ and $\left.\mathrm{SiO}_{2}\right)$, and smaller amounts of lime, alumina, and magnesia $\left(\mathrm{CaO}, \mathrm{Al}_{2} \mathrm{O}_{3}\right.$, and $\left.\mathrm{MgO}\right)$ as well as some minor elements (antimony, lead, bismuth, tin, and arsenic) [6-10]. The copper smelting slag is often referred to as fayalite slag $\left(\mathrm{Fe}_{2} \mathrm{SiO}_{4}\right)$, and usually has a copper content of about $1-2 \mathrm{wt} \%$ [6]. The chemical composition of the slag influences the slag properties, which in turn,

influences the settling of mechanically entrained copper in the slag. These slag properties are viscosity, density, interfacial tension, and melting temperature [11].

The natural separation between the copper-containing phases and the molten slag phase is due to the density difference between the phases. The settling rate of entrained droplets in a molten slag can be described according to Stokes law (Equation (1)), where increasing density difference between the phases or decreased viscosity results in an increased settling rate [12]. The settling rate $v\left(\mathrm{~m} \mathrm{~s}^{-1}\right)$ is a function of gravitational acceleration $g$ $\left(\mathrm{m} \mathrm{s}^{-2}\right)$, the copper droplet diameter $d(\mathrm{~m})$, the density of the copper droplet $\rho_{d}\left(\mathrm{~kg} \mathrm{~m}^{-3}\right)$, the slag density $\rho_{s}\left(\mathrm{~kg} \mathrm{~m}^{-3}\right)$ and the fluid dynamic viscosity $\mu\left(\mathrm{kg} \mathrm{m}^{-1} \mathrm{~s}^{-1}\right)$.

$$
v=\frac{g d^{2}}{18}\left(\frac{\rho_{d}-\rho_{s}}{\mu}\right)
$$

A possible way to decrease the copper losses is to modify the slag to enhance the essential properties for an increased settling rate. In the literature, the effect of $\mathrm{CaO}$ on the slag properties and the slag copper content has mainly been studied in experimental trials and not in slag cleaning routes. The effect of $\mathrm{CaO}$ addition on the viscosity has been examined with similar results, decreasing with the $\mathrm{CaO}$ addition [13-17]. The influence of $\mathrm{CaO}$ on the viscosity was most significant in the temperature range between 1200 and $1250{ }^{\circ} \mathrm{C}$ [13]. The theory behind the decreased viscosity of the molten slag is that the metal oxide $\mathrm{CaO}$ breaks the silicate polyions into smaller structural units, which thus decreases the slag viscosity. The viscosity of slags with the $\mathrm{Fe} / \mathrm{SiO}_{2}(\mathrm{wt} \% / \mathrm{wt} \%$ ) ratio above 1.2 decreased with increasing ratio, which was explained by the depolymerization of the three-dimensional silicate network in the slag [13,14]. Aluminate is another possible network forming cation in slag, which increases the degree of polymerization and thus the slag viscosity [18]. In a study by Park et al., the viscosity in an iron silicate slag first decreased with the addition of $\mathrm{Al}_{2} \mathrm{O}_{3}$ up to $5 \mathrm{wt} \%$. However, with higher additions, the slag viscosity increased. The effect was suggested to be related to the amphoteric behavior of $\mathrm{Al}_{2} \mathrm{O}_{3}$, acting as a basic oxide at lower additions and as an acidic oxide at higher additions. The effect could also have been due to the modification of the liquidus temperature [19]. $\mathrm{CaO}, \mathrm{MgO}$, and $\mathrm{Al}_{2} \mathrm{O}_{3}$ are minor oxides occurring in the ESF slag at the Boliden Rönnskär smelter.

The viscosity also correlates with the temperature, and in general, the viscosity in slag decreases with increasing temperature [19-21]. According to Chen et al., the viscosities of iron silicate slags are more sensitive to changes in temperature at higher $\mathrm{SiO}_{2}$ concentrations [22]. The slag in the settling furnace at the Boliden Rönnskär smelter has a $\mathrm{Fe} / \mathrm{SiO}_{2}$ ratio of close to unity, indicating that the viscosity of the slag could be relatively high and sensitive to temperature changes.

The slag viscosity is also affected by solid phases, where the viscous behavior of liquid melts containing solid phases increases linearly with increasing content of solids [23]. Sukhomlinow et al. studied the chromium solubility in $\mathrm{Al}_{2} \mathrm{O}_{3}-\mathrm{CaO}-\mathrm{FeO}-\mathrm{SiO}_{2}$ slags as a function of oxygen partial pressure $\left(\mathrm{P}_{2}\right)$ and the effect of $\mathrm{Al}_{2} \mathrm{O}_{3}$ and $\mathrm{CaO}$. The results showed that the chromium solubility was $\sim 0.15 \mathrm{wt} \%$ when the $\mathrm{P}_{\mathrm{O} 2} \approx 10^{-5}$ and increased to $0.30 \mathrm{wt} \%$ when the $\mathrm{P}_{\mathrm{O} 2} \approx 10^{-10}$. The addition of $\mathrm{CaO}$ and $\mathrm{Al}_{2} \mathrm{O}_{3}$ slightly increased the 
chromium solubility in the slag, independent of the oxygen partial pressure. At chromium contents above the chromium solubility, chromium precipitated as a ferrous chromite spinel with some dissolved alumina [24]. The ferrous chromite spinel phase is denser compared to the slag phase, which leads to the accumulation of chromium in the furnace vessel. The increased viscosity due to solid phases is an additional reason for controlling the presence of solid phases in the liquid slag.

As mentioned, other slag properties that influence the settling are density and interfacial tension. In previous studies, a rapid separation and settling of matte droplets have been observed within the first 10-15 min due to the density difference between the copper and slag phases $[25,26]$. The separation rate then decreased as other physical properties, such as viscosity or surface tension, became rate-determining, and the matte phase needs to form big enough droplets to settle. Zhang et al. claimed that the density of iron-rich slags decreases with the addition of $\mathrm{CaO}$ [15]. The surface tension of slag is also influenced by the $\mathrm{CaO}$ modification, increasing with increasing $\mathrm{CaO}$ content $[15,27]$. The tendency for coalescence should increase with increasing interfacial tension between the coppercontaining phase and slag [28], thus increasing the size of the copper droplets, which, in turn, increases the settling rate.

Another enhancement from the addition of $\mathrm{CaO}$ to iron silicate slag is the copper solubility in slag, which decreases with the addition $[29,30]$. The decreased solubility is explained by the acid-base theory of slags, where, e.g., $\mathrm{Ca}^{2+}$ ions in $\mathrm{CaO}$ replace some of the $\mathrm{Cu}^{+}$ions within the silicate structure of the slag [29]. The effect enhances the settling as more copper becomes entrained instead of dissolved in the slag.

In an earlier study in the settling furnace, the slag copper content was concluded to increase with increasing temperature within a given interval [4], which could be due to increased copper solubility at higher temperatures $[10,31,32]$. The final slag copper content was also suggested to be more strongly correlated to the temperature compared to the settling time in the furnace. The $\mathrm{CaO}$ modification of slag enhances the properties that improve the settling of copper-containing droplets in slag, without increasing the copper solubility. $\mathrm{CaO}$ is thus a possible additive to the industrial slag cleaning processes of pyrometallurgical copper extraction. In the literature, there is limited information about the effect of $\mathrm{CaO}$ modification on the final slag copper content in an industrial slag cleaning system where the slag is treated and modified in a fuming furnace prior to the settling process. In the present work, the term 'slag' refers to an iron silicate phase with minor oxides including e.g., $\mathrm{Al}_{2} \mathrm{O}_{3}, \mathrm{CaO}$, and $\mathrm{MgO}$. In addition, the slag contains inclusions of matte and speiss droplets and other oxide phases. A slag characterization and the copper-containing phases can be found in a previous study of the slag system without the modification of $\mathrm{CaO}$ [4]. The aim of the present work was to examine if industrial $\mathrm{CaO}$ modification can decrease the final copper content of the slag, after treatment in a fuming furnace and then in an electric settling furnace.

\section{Materials and Methods}

\subsection{Settling Furnace and Trial Description}

The flowsheet of the ESF slag is presented in Figure 1a together with a schematic of the electric settling furnace in Figure 1b. The slag is tapped from the ESF into ladles, which are transferred and tapped into the fuming furnace. The slag is tapped from the fuming furnace via a slag runner and charging funnel into the settling furnace (top right in Figure 1b), then tapped and water granulated (to the left in Figure 1b) and transported to dewatering basins. The operation in the fuming furnace and settling furnace is operated batch-wise, where the slag is tapped out of the settling furnace after the given settling time. The copper phases accumulate in the settling furnace from several batches and are tapped once a day (tap hole marked with matte and speiss tapping in Figure 1b). 


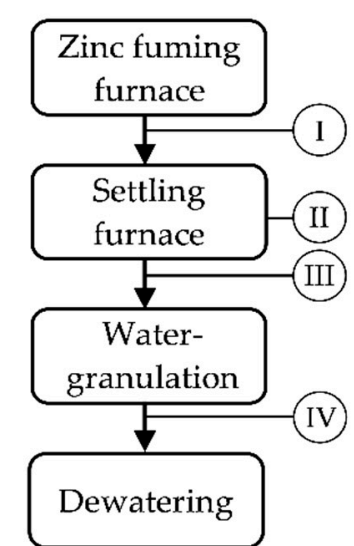

(a)

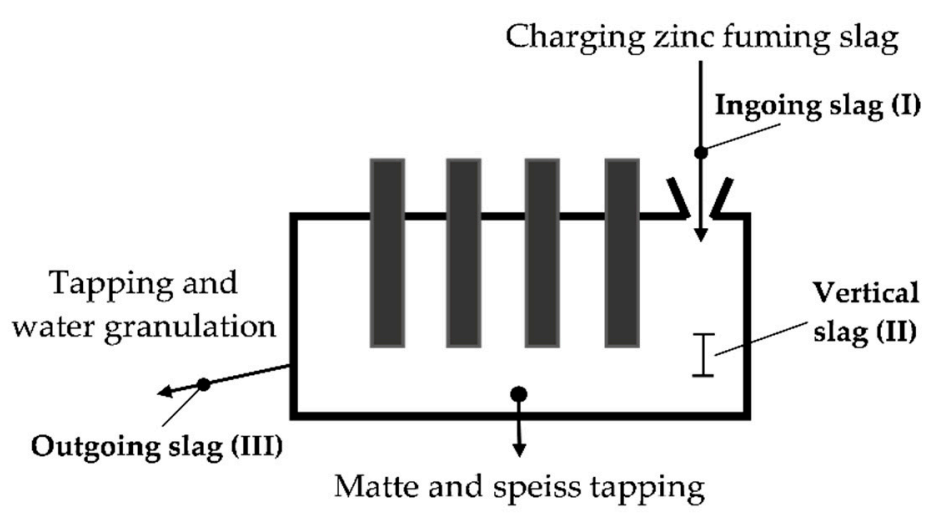

(b)

Figure 1. (a) Flowsheet of the ESF slag with the sample points for the ingoing (I), vertical (II), outgoing (III), and granulated (IV) slag; (b) Schematic of the electric settling furnace.

The $\mathrm{CaO}$ content was varied between the batches by adding limestone $\left(\mathrm{CaCO}_{3}\right)$, provided by Nordkalk $\mathrm{AB}$, at the beginning of the fuming process with the target content of 5,10 , and $15 \mathrm{wt} \% \mathrm{CaO}$, and one reference batch without $\mathrm{CaCO}_{3}$ addition $(\mathrm{Cl}$, denoted as 'Reference' in Table 1). The added $\mathrm{CaCO}_{3}$ will undergo calcination during the treatment in the fuming furnace producing $\mathrm{CaO}$ and $\mathrm{CO}_{2}$. During normal operation, the $\mathrm{CaO}$ content varies between 3-4 wt \% in the settling furnace slag. The settling time in the furnace was kept constant to $\sim 15$ min during the trial. The definition of the settling time; starts when the charging into the settling furnace is finalized and stops when the water granulation starts. The process is described in more detail in an earlier study [4]. Table 1 provides details of the evaluated batches, which are denoted as C1-C5.

Table 1. Evaluated batches and the target $\mathrm{CaO}$ content, temperatures, and settling times.

\begin{tabular}{ccccc}
\hline & $\mathbf{( w t} \mathbf{~ o )}$ & \multicolumn{2}{c}{$\left({ }^{\circ} \mathbf{C}\right)$} & $(\mathbf{m i n})$ \\
\cline { 2 - 5 } Batch & CaO & $\begin{array}{c}\text { Fuming } \\
\text { Temperature }\end{array}$ & $\begin{array}{c}\text { Settling } \\
\text { Temperature }\end{array}$ & Settling Time \\
\hline C1 & Reference & 1247 & 1247 & 13 \\
C2 & 5 & 1247 & 1252 & 19 \\
C3 & 10 & 1216 & 1249 & 21 \\
C4 & 10 & 1192 & 1223 & 13 \\
C5 & 15 & 1212 & 1250 & 14 \\
\hline
\end{tabular}

\subsection{Slag Sampling during the Trial}

In total, four sample points were used as the basis for the evaluation of copper content in the slag and the effect of $\mathrm{CaO}$ modification. Slag samples were collected from several sample points as entrained copper phases may not be homogeneously distributed within the slag layer, which in turn influences the chemical analysis of copper. The samples from the four sample points are named: ingoing slag, outgoing slag, vertical slag samples, and granulated slag.

Ingoing slag samples (" $\mathrm{I}$ " in Figure 1a,b) were collected in the slag stream during the tapping from the fuming furnace into the settling furnace every $5 \mathrm{~min}$. The samples were collected with steel scoops lowered into the slag stream and cooled in the ambient air. In total, three samples were collected, in the beginning, in the middle, and at the end of the tapping. Outgoing slag samples ("III" in Figure 1a,b) were collected in the slag stream during the tapping from the settling furnace according to the same procedure as the ingoing slag. The sample was collected every $15 \mathrm{~min}$ resulting in five samples per batch. The sampling of the granulated slag ("IV" in Figure 1a) was collected from the water 
stream with granules in the middle of the water granulation process (after $\sim 30 \mathrm{~min}$ ) before the granules reached the dewatering basins.

Vertical slag samples ("II" in Figure 1a,b) were collected from within the furnace with a steel rod lowered into the slag layer through the charging funnel. The steel rod was lowered to a depth where it touched the bottom buildup, which was known to be present in the furnace during the trial. This was done to ensure that the entire slag layer was represented on the steel rod. A schematic of the settling furnace with the slag phase, copper phases, and the bottom buildup is presented to the left in Figure 2. However, the bottom buildup profile in Figure 2 is an estimation to clarify the sampling of the vertical slag samples. The vertical slag sample on the steel rod was cooled in the ambient air and held over a box with different levels, which had a spacing of $\sim 0.1 \mathrm{~m}$. The slag from the bottom layer corresponds to level 1, while slag from the top layer corresponds to level 5 or 6 , depending on the slag layer thickness in the furnace. A schematic of the steel rod and box is presented to the right in Figure 2. The dark phase on the steel rod represents the slag layer from the marked area within the settling furnace. In this scenario, the slag layer had a height of about $0.6 \mathrm{~m}$ and thus corresponds to six vertical slag level samples.

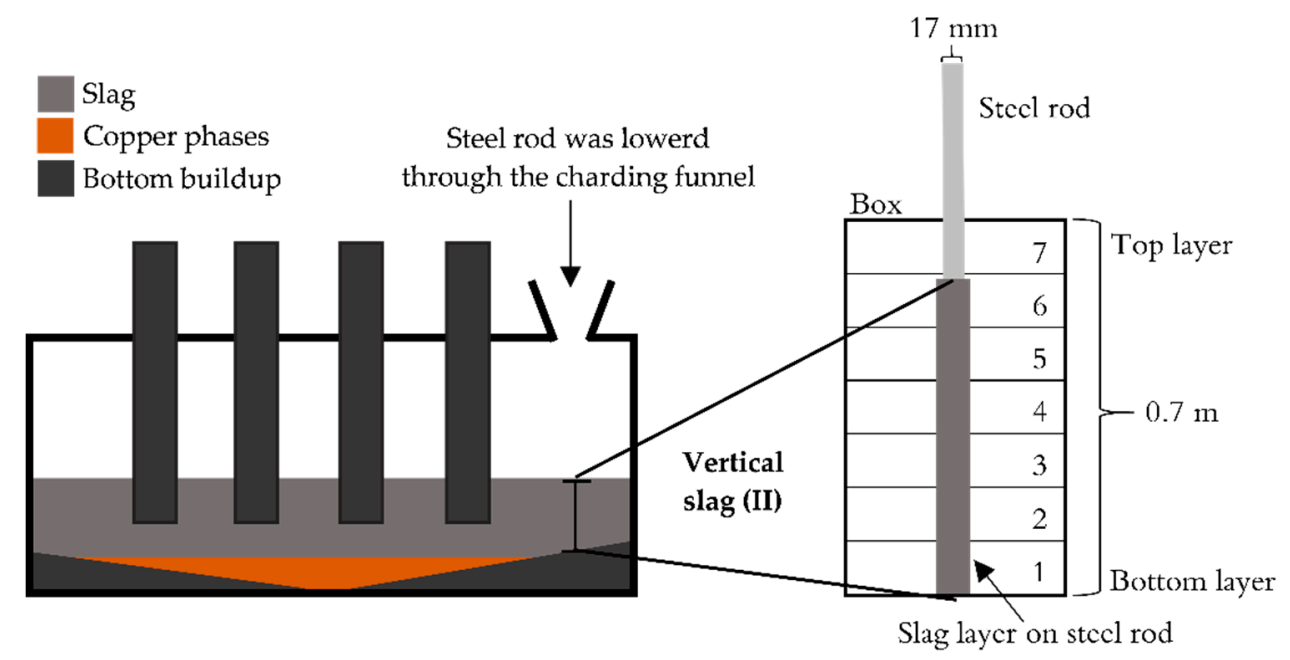

Figure 2. Schematic of the electric settling furnace and the steel rod and box used to collect and divide vertical slag samples into different levels.

\subsection{Experimental Procedure}

Samples of ingoing and outgoing slag were analyzed at the smelter laboratory at Boliden Rönnskär, with their standardized method using a Philips PW2606 X-ray fluorescence (XRF) instrument (Malvern Panalytical, Malvern, UK). The copper content in the ingoing slag and the granulated slag was analyzed with an Agilent 280 FS AA instrument (Flame atomic absorption spectroscopy, FAAS) (Agilent Technologies, Santa Clara, CA, USA) in the same laboratory.

All vertical slag samples (Sections 1-3 and 4 or 5), collected at the settling start and end, and a replicate of the ingoing slag sample were sent for chemical analysis to a certified laboratory (ALS Scandinavia AB, Luleå, Sweden). The samples were analyzed with a Thermo Finnigan Element 1 inductively coupled plasma-sector field mass spectroscopy (ICP-SFMS) instrument (Thermo Fisher Scientific, Waltham, MA, USA). Before the ICPSFMS analysis, the samples were split in two and digested with two different methods. The oxides $\mathrm{SiO}_{2}, \mathrm{FeO}, \mathrm{Al}_{2} \mathrm{O}_{3}, \mathrm{CaO}, \mathrm{MgO}$, and $\mathrm{Cr}$ were analyzed in a solution from the first digestion method, including fusion with lithium metaborate and digestion in nitric acid. $\mathrm{Cu}, \mathrm{Pb}, \mathrm{Zn}$, and $\mathrm{Sb}$ were analyzed in a solution from the second method including digested in a mixture of nitric acid, hydrochloric acid, and hydrofluoric acid during heating.

The contents of $\mathrm{Fe}, \mathrm{Cr}, \mathrm{Pb}$, and $\mathrm{Zn}$ were recalculated as those of the corresponding oxides. The results of all slag compositions were normalized, so the sum of the content 
became $100 \mathrm{wt} \%$. The ingoing and outgoing copper content is presented as an average with the related standard deviation.

The copper recovery in the settling furnace was calculated with Equation (2), where $\% C u_{\text {ingoing }}$ is the average weight percent copper in the ingoing slag, and $\% C u_{\text {outgoing }}$ is an average of the weight percent copper in the outgoing and granulated slag. The difference in mass of the ingoing slag and granulated slag was assumed to be negligible. The sample of the granulated slag from C 3 was missing, the calculation of the copper recovery is thus based on the analysis of the outgoing slag for this batch.

$$
\text { Copper recovery }[\%]=100 \% \cdot \frac{\% C u_{\text {ingoing }}-\% C u_{\text {outgoing }}}{\% C u_{\text {ingoing }}}
$$

\section{Results and Discussion}

The compositions of the average ingoing slag with different $\mathrm{CaO}$ content are presented in Table 2, where the $\mathrm{CaO}$ content increases in the following order $\mathrm{C} 1, \mathrm{C} 2, \mathrm{C} 4, \mathrm{C} 3$, and $\mathrm{C} 5$. The six analysis (two replicates of three samples) of the ingoing slag copper content was statistically evaluated using a box plot, and two values were excluded, one from $\mathrm{C} 1$ and one from C4. The box plot can be seen in Figure 3a, where the two outliers are marked as grey dots. An average was calculated for the remaining values of the copper content, which is presented in Figure $3 b$, together with the error bars, which equals \pm one standard deviation (st.d). The average ingoing copper content is independent of the $\mathrm{CaCO}_{3}$ addition as the copper content in the slag originates from the ESF slag. The average ingoing copper content was lowest in $\mathrm{C} 1$ and highest in $\mathrm{C} 5$, with the corresponding copper content of $1.2 \mathrm{wt} \%$ and $1.7 \mathrm{wt} \%$.

Table 2. Normalized compositions of the ingoing slag and the standard deviation of copper (st.d $\mathrm{Cu}$ ) for batch $\mathrm{C} 1-\mathrm{C} 5$.

\begin{tabular}{cccccccccccc}
\hline \multirow{2}{*}{ Batch } & \multicolumn{10}{c}{$\mathbf{( w \mathbf { \% } )}$} \\
\cline { 2 - 12 } & $\mathbf{S i O}_{\mathbf{2}}$ & $\mathbf{F e O}$ & $\mathbf{A l}_{\mathbf{2}} \mathbf{O}_{\mathbf{3}}$ & $\mathbf{C a O}$ & $\mathbf{M g O}$ & $\mathbf{C r}_{\mathbf{2}} \mathbf{O}_{\mathbf{3}}$ & $\mathbf{Z n O}$ & $\mathbf{A s}$ & $\mathbf{S b}$ & $\mathbf{C u}$ & $\mathbf{S t . d ~ C u}$ \\
\hline $\mathrm{C} 1$ & 39 & 49 & 5.2 & 3.3 & 1.4 & 0.25 & 0.74 & 0.06 & 0.10 & 1.2 & 0.16 \\
$\mathrm{C} 2$ & 36 & 47 & 4.8 & 8.8 & 1.3 & 0.24 & 0.74 & 0.08 & 0.12 & 1.4 & 0.15 \\
$\mathrm{C} 3$ & 32 & 43 & 4.4 & 16 & 1.9 & 0.30 & 0.53 & 0.21 & 0.31 & 1.6 & 0.18 \\
$\mathrm{C} 4$ & 33 & 44 & 4.3 & 15 & 1.7 & 0.18 & 0.97 & 0.15 & 0.34 & 1.4 & 0.08 \\
$\mathrm{C} 5$ & 34 & 37 & 4.0 & 20 & 1.6 & 0.14 & 0.91 & 0.11 & 0.33 & 1.7 & 0.21 \\
\hline
\end{tabular}
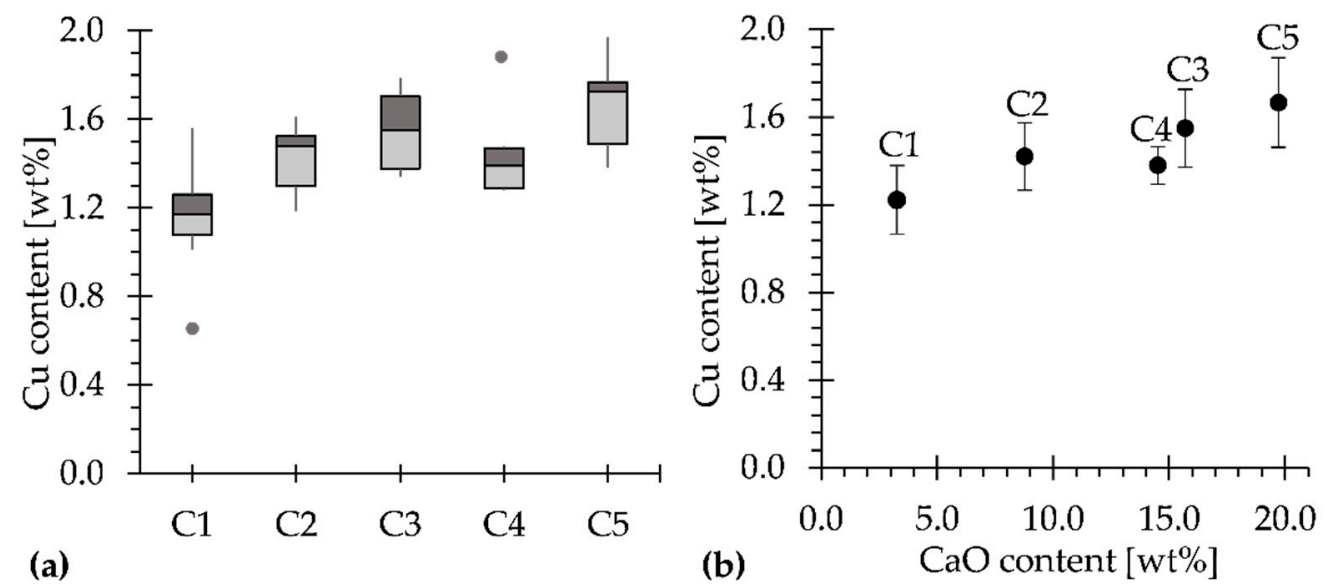

Figure 3. (a) Box plot of the ingoing copper content in batch $\mathrm{C} 1-\mathrm{C} 5$; (b) The average ingoing copper content in batch $\mathrm{C} 1-\mathrm{C} 5$ with corresponding standard deviation plotted against the $\mathrm{CaO}$ content. 
Table 3 presents the composition of the (average) outgoing slag and the granulated slag. The $\mathrm{Fe} / \mathrm{SiO}_{2}$ ratio (wt \%/wt \%) was based on the compositions of the granulated slag (from Table 3) and varied from 0.79-0.97, highest in C1 and lowest in C5. The average $\mathrm{CaO}$ content in the outgoing slag increased from $3.1 \mathrm{wt} \%$ in $\mathrm{C} 1$ to 17 wt \% in $\mathrm{C} 5$. The $\mathrm{CaO}$ content of the outgoing slag differs from that of the ingoing slag, which was ascribed to a dilution effect when the slag remaining from the previous batch was mixed with new slag tapped into the settling furnace.

Table 3. Normalized compositions of average outgoing (out.) slag and the granulated slag (gran.), and the standard deviation of copper. The sample of the granulated slag was missing for C3. The sulfur content was only analyzed for the granulated slag (FAAS method).

\begin{tabular}{|c|c|c|c|c|c|c|c|c|c|c|c|c|c|c|}
\hline \multirow{2}{*}{ Batch } & & \multicolumn{13}{|c|}{ (wt \%) } \\
\hline & & $\mathrm{SiO}$ & $\mathrm{FeO}$ & $\mathrm{Al}_{2} \mathrm{O}_{3}$ & $\mathrm{CaO}$ & $\mathrm{MgO}$ & $\mathrm{ZnO}$ & $\mathrm{Cr}_{2} \mathrm{O}_{3}$ & As & $S$ & $\mathrm{Ni}$ & $\mathrm{Sb}$ & $\mathrm{Cu}$ & St.d Cu \\
\hline \multirow[b]{2}{*}{$\mathrm{C} 1$} & out. & 39 & 49 & 5.0 & 3.1 & 1.5 & 0.9 & 0.31 & 0.04 & & 0.04 & 0.02 & 0.64 & 0.03 \\
\hline & gran. & 39 & 49 & 4.3 & 3.1 & 1.2 & 1.5 & 0.23 & 0.02 & 0.52 & 0.04 & 0.02 & 0.77 & \\
\hline \multirow{2}{*}{$\mathrm{C} 2$} & out. & 38 & 46 & 5.1 & 7.0 & 1.5 & 0.9 & 0.30 & 0.06 & & 0.05 & 0.01 & 0.55 & 0.02 \\
\hline & gran. & 37 & 47 & 4.4 & 7.2 & 1.2 & 1.4 & 0.23 & 0.01 & 0.41 & 0.03 & 0.01 & 0.61 & \\
\hline \multirow{2}{*}{$\mathrm{C} 3$} & out. & 37 & 41 & 5.8 & 12 & 1.8 & 0.6 & 0.34 & 0.04 & & 0.04 & 0.07 & 0.62 & 0.03 \\
\hline & gran. & - & - & - & - & - & - & - & - & - & - & - & - & \\
\hline \multirow{2}{*}{$\mathrm{C} 4$} & out. & 36 & 42 & 5.4 & 13 & 1.7 & 1.0 & 0.29 & 0.06 & & 0.04 & 0.02 & 0.55 & 0.06 \\
\hline & gran. & 34 & 45 & 3.6 & 12 & 1.4 & 1.6 & 0.23 & 0.02 & 0.52 & 0.02 & 0.01 & 0.57 & \\
\hline \multirow{2}{*}{ C5 } & out. & 37 & 37 & 6.1 & 17 & 1.6 & 1.0 & 0.27 & 0.06 & & 0.03 & 0.02 & 0.55 & 0.03 \\
\hline & gran. & 34 & 41 & 3.7 & 16 & 1.3 & 1.6 & 0.21 & 0.01 & 0.41 & 0.01 & 0.01 & 0.57 & \\
\hline
\end{tabular}

Figure 4a presents a box plot of the copper content in all samples of the outgoing slag in batch C1-C5. Two values are marked as outliers (grey dots) in the plot, these values were excluded from the calculated average copper content in the batches (presented in Table 3). Figure $4 \mathrm{~b}$ presents the copper content in the outgoing and granulated slag plotted against the $\mathrm{CaO}$ content. The slag copper content decreased with increasing $\mathrm{CaO}$ content in the granulated slag from $0.77 \mathrm{wt} \%$ in $\mathrm{C} 1$ to $0.57 \mathrm{wt} \%$ in $\mathrm{C} 4$ and $\mathrm{C} 5$. For the outgoing slag, the copper content is highest in $\mathrm{C} 1(0.64 \mathrm{wt} \%)$ and lowest for C2, C4, and C5 (0.55 wt \%). The settling temperature was about the same $\left(1247-1252^{\circ} \mathrm{C}\right.$, Table 1$)$ for all batches except for $\mathrm{C} 4$, which had a temperature of $1223{ }^{\circ} \mathrm{C}$. No correlation was observed between the outgoing slag copper content and the temperature.

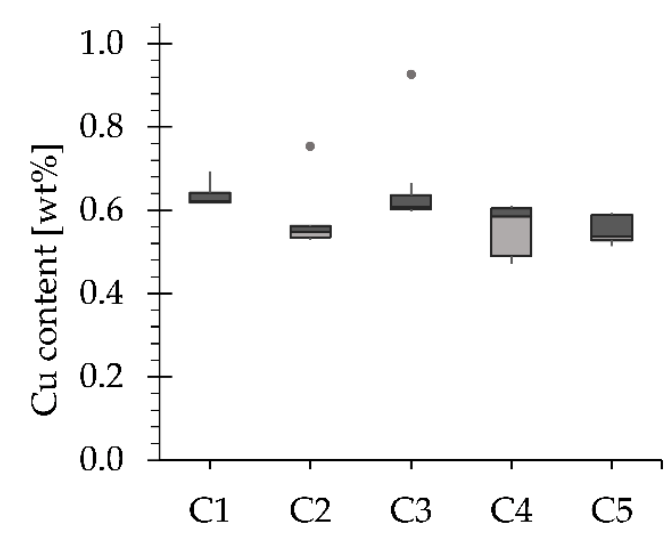

(a)

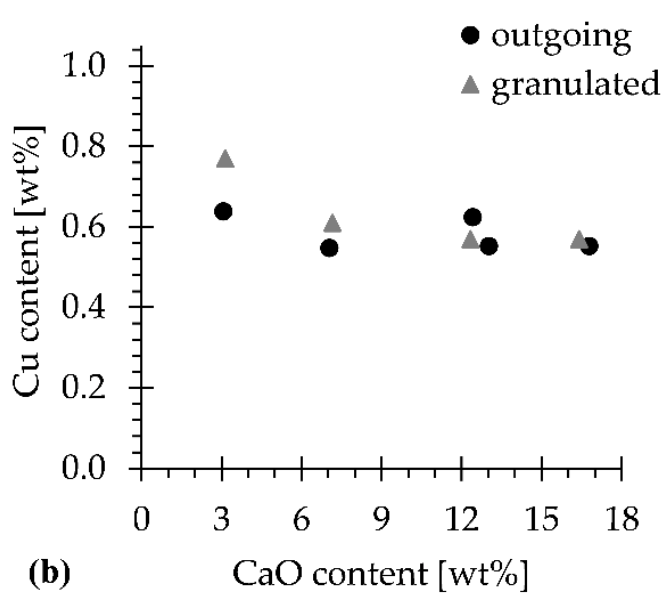

(b)

Figure 4. (a) Box plot of the copper content in the outgoing slag for batch C1-C5; (b) Copper content in outgoing slag and granulated slag plotted against the $\mathrm{CaO}$ content.

The ingoing copper content differed between the batches (Figure 3), highest in C5 and lowest in $\mathrm{C} 1$. This means that the copper content was not diluted with the $\mathrm{CaO}$ modification. Higher ingoing slag copper content means that a larger quantity of copper needs to settle to achieve the same final slag copper content, compared to a batch with 
lower ingoing slag copper content. Figure 5 presents the effect of the $\mathrm{CaO}$ content on the copper recovery in the settling furnace, which was calculated according to Equation (2). The copper recovery was lowest in $\mathrm{C} 1$, without $\mathrm{CaO}$ modification, and highest in $\mathrm{C} 5$, which had the highest content of $\mathrm{CaO}$. The most significant decrease in slag copper content was when the $\mathrm{CaO}$ content increased from $3.1 \mathrm{wt} \%$ to $7.2 \mathrm{wt} \%$, with the corresponding copper recovery of $42 \%$ and $59 \%$, respectively (C1 and C2). Batch $C 5$, had the highest recovery of $66 \%$. A contributing factor to the increased recovery between $\mathrm{C} 4$ and $\mathrm{C} 5$ is the ingoing copper content, which was $1.6 \mathrm{wt} \%$ in C4 and $1.7 \mathrm{wt} \%$ in C5 (Figure 3), the outgoing slag copper content was equal in the two batches.

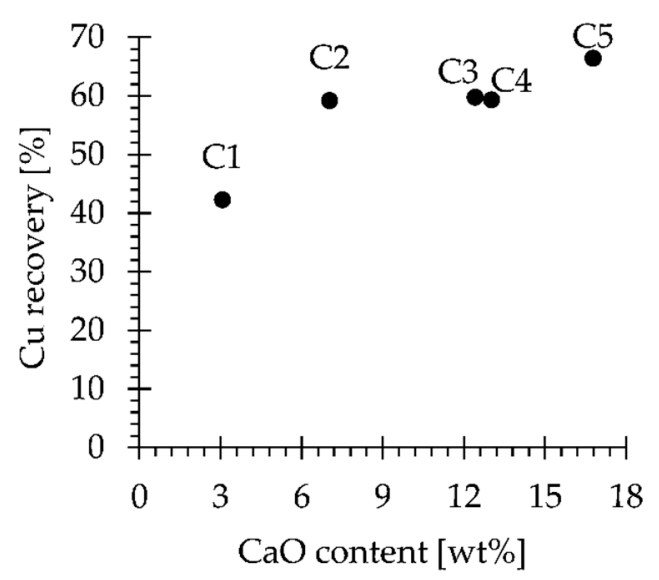

Figure 5. Copper recovery between the copper phases and the slag phase.

Entrained copper droplets of the same size have equal settling velocity independent of the total slag copper content. This means that if a batch has a higher ingoing copper content, with droplet sizes within a range that they will have time to settle under the given settling time, a higher amount of copper will be distributed to the underlying copper phase. In this work, the size distribution of copper-containing phases is unknown and thus both the copper recovery and the final copper content in the slag must be evaluated to see the effect of slag modification. The final slag copper content in the outgoing and granulated slag and the copper recovery indicate that the settling of copper phases was more efficient with the $\mathrm{CaO}$ modification of the slag.

The content of $\mathrm{Cu}, \mathrm{CaO}$, and $\mathrm{Cr}_{2} \mathrm{O}_{3}$ in the vertical slag samples from batches $\mathrm{C} 1-\mathrm{C} 5$ are shown in Table 4. The other slag components were about equal at all levels and similar to the outgoing and granulated slag (Table 3). No slag sample was analyzed from the second-highest level in batch C2 (start of the settling) due to a too-small sample amount. The vertical slag sample from level 1 is the bottom-most slag layer, level 2 second-lowest, and level 4 or 5 corresponds to the second-highest slag level in the furnace during sampling.

Figure 6a presents the effect of $\mathrm{CaO}$ modification on the copper content in vertical slag samples at the settling end. The copper content at levels 3 and 2 decreased with the $\mathrm{CaO}$ content up to $\sim 11 \mathrm{wt} \%$ (from $0.73 \mathrm{wt} \%$ (C1) to $0.51 \mathrm{wt} \%$ (C4) at level 2). The copper content at level 2 in $\mathrm{C} 3$ deviates and is higher compared to the copper content in C4, which has approximately the same $\mathrm{CaO}$ content. The upper levels (level 3 and 4) of the vertical slag samples from $\mathrm{C} 3$ had a higher copper content at the settling start compared to C4, which affects the copper content in the lower levels. The copper content in the top layers influences the content in the lower levels as the entrained copper droplets descend through the slag until they reach the underlying copper phases. The copper content in the highest level analyzed (settling end) was lowest in C 3 , with a value of $0.56 \mathrm{wt} \%$ and a $\mathrm{CaO}$ content of $11 \mathrm{wt} \%$. The decreasing copper content indicates that the settling of copper-containing phases becomes more efficient with the $\mathrm{CaO}$ modification up to $\sim 11 \mathrm{wt} \%$. 
Table 4. Copper content at the settling start and end in vertical slag samples from $\mathrm{C} 1-\mathrm{C} 5$, and the average $\mathrm{Cu}, \mathrm{CaO}$, and $\mathrm{Cr}_{2} \mathrm{O}_{3}$ content based on levels $5 / 4,3$, and 2 .

\begin{tabular}{|c|c|c|c|c|c|c|c|}
\hline \multirow[b]{2}{*}{ Batch } & & \multirow[b]{2}{*}{ Settling } & \multicolumn{5}{|c|}{ (wt \%) } \\
\hline & & & Level 4/5 & Level 3 & Level 2 & Level 1 & Average * \\
\hline \multirow[t]{4}{*}{$\mathrm{C} 1$} & & Start & 0.98 & 0.98 & 1.1 & 1.4 & 1.0 \\
\hline & $\mathrm{Cu}$ & End & 0.72 & 0.78 & 0.73 & 0.85 & 0.74 \\
\hline & $\mathrm{CaO}$ & & & & & & 2.8 \\
\hline & $\mathrm{Cr}_{2} \mathrm{O}_{3}{ }^{* *}$ & & & & & $0.98-1.2$ & 0.23 \\
\hline \multirow[t]{4}{*}{$\mathrm{C} 2$} & & Start & - & 0.75 & 0.71 & 0.89 & 0.73 \\
\hline & & End & 0.79 & 0.65 & 0.58 & 0.79 & 0.67 \\
\hline & $\mathrm{CaO}$ & & & & & & 6.3 \\
\hline & $\mathrm{Cr}_{2} \mathrm{O}_{3} * *$ & & & & & $1.4-1.0$ & 0.21 \\
\hline \multirow{4}{*}{ C3 } & & Start & 0.77 & 0.73 & 0.74 & 0.87 & 0.75 \\
\hline & $\mathrm{Cu}$ & End & 0.56 & 0.61 & 0.66 & 1.8 & 0.61 \\
\hline & $\mathrm{CaO}$ & & & & & & 11 \\
\hline & $\mathrm{Cr}_{2} \mathrm{O}_{3}{ }^{* *}$ & & & & & $2.6-1.6$ & 0.32 \\
\hline \multirow{4}{*}{$\mathrm{C} 4$} & & Start & 0.66 & 0.60 & 0.66 & 2.1 & 0.64 \\
\hline & $\mathrm{Cu}$ & End & 0.60 & 0.58 & 0.51 & 1.2 & 0.56 \\
\hline & $\mathrm{CaO}$ & & & & & & 11 \\
\hline & $\mathrm{Cr}_{2} \mathrm{O}_{3}{ }^{* *}$ & & & & & $2.7-3.5$ & 0.34 \\
\hline \multirow{4}{*}{ C5 } & & Start & 0.73 & 0.86 & 0.90 & 0.73 & 0.83 \\
\hline & $\mathrm{Cu}$ & End & 0.64 & 0.61 & 0.54 & 0.86 & 0.60 \\
\hline & $\mathrm{CaO}$ & & & & & & 15 \\
\hline & $\mathrm{Cr}_{2} \mathrm{O}_{3}^{* *}$ & & & & & $0.83-5.7$ & 0.38 \\
\hline
\end{tabular}

${ }^{*}$ Average $\mathrm{Cu}, \mathrm{CaO}$, and $\mathrm{Cr}_{2} \mathrm{O}_{3}$ content, all samples besides level 1. ${ }^{* *} \mathrm{Cr}_{2} \mathrm{O}_{3}$ content at level 1 (start-end value) and the average of levels $4 / 5,3$, and 2 .

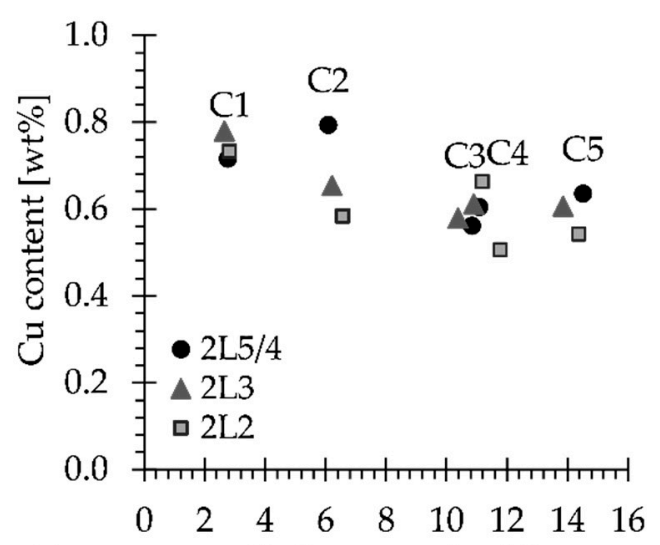

(a) $\mathrm{CaO}$ content $[\mathrm{wt} \%]$

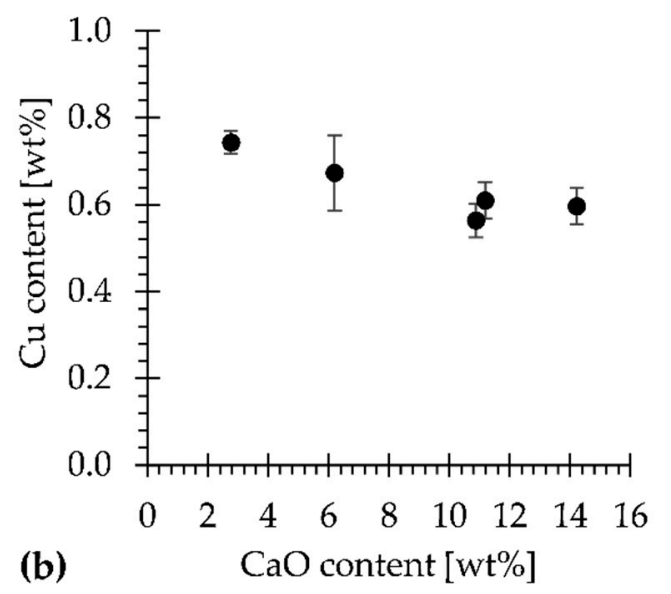

Figure 6. (a) Copper content versus $\mathrm{CaO}$ content in vertical slag samples (settling end). The samples are denoted as XLY, where $X$ corresponds to the collection time (start of settling $=1$, end of settling $=2$ ). LY relates to the sample level (level $\mathrm{Y}=\mathrm{LY}$ ); (b) Average copper content versus average $\mathrm{CaO}$ content in batch $\mathrm{C} 1-\mathrm{C} 5$.

Figure $6 \mathrm{~b}$ presents the average copper content (levels $5 / 4,3$, and 2) at the settling end together with the corresponding standard deviation, plotted against the average $\mathrm{CaO}$ content in each batch. The average copper content in the level samples shows the same trend as the copper content in the outgoing and granulated slag, which decreases with increasing $\mathrm{CaO}$ content. The average copper content in the level samples decreased from $0.74 \mathrm{wt} \%$ in $\mathrm{C} 1$ to $0.56 \mathrm{wt} \%$ in C4. The average copper content of each batch can be found in Table 4. 
The reviewed literature revealed that the $\mathrm{CaO}$ modification decreases the viscosity of the slag [13-17]. A decreased viscosity increases the settling rate of entrained droplets according to Stokes law (Equation (1)) [22]. This is consistent with the observations in the evaluated industrial trial, where the final slag copper content decreased and copper recovery increased with the $\mathrm{CaO}$ modification. In theory, a decreased slag viscosity enhances the settling rate of the mechanically entrained copper droplets as the internal friction of the slag decreases [23]. In most of the literature, where the viscosity is investigated in iron silicate slags, the $\mathrm{Fe} / \mathrm{SiO}_{2}$ ratio is 1.2 or higher. Kaiura suggested that the viscosity decreased as the composition moved away from silica saturation, which was explained by the depolymerization of the three-dimensional silicate network [13]. The slag from the ESF at the Boliden Rönnskär smelter has a $\mathrm{Fe} / \mathrm{SiO}_{2}$ ratio close to unity, meaning that the slag is rich in silica. The relatively low $\mathrm{Fe} / \mathrm{SiO}_{2}$ ratio in the slag in the settling furnace indicates that the viscosity is rather high without the modification with $\mathrm{CaO}$. The effect on the copper content is not as clear at $\mathrm{CaO}$ contents above $11 \mathrm{wt} \%$ in the vertical slag samples, which is consistent with the copper content in the outgoing and granulated slag. The decreasing effect of $\mathrm{CaO}$ on the copper content is due to changed slag properties or because of the ingoing copper content, which increased from $\mathrm{C} 1$ to $\mathrm{C} 5$.

Figure 7 presents the chromium oxide content for all vertical slag samples (settling end). The vertical slag level ( $y$-axis) represents the position in the slag layer, the highest level analyzed is level 4 or 5 and the bottom-most slag layer is level 1 . The figure shows that the chromium content increases towards the bottom of the slag layer which contacts the bottom buildup and consists of a chromium spinel, which attaches to copper droplets [4]. The high chromium oxide content in the bottom-most samples indicates that part of the bottom buildup is present in the sample. Level-1 samples were thus excluded from Figure $6 \mathrm{a}, \mathrm{b}$ due to the possible presence of the chromium spinel, which influences the copper content. The chromium oxide content in the outgoing slag was similar to the content at levels 2, 3, and level $5 / 4$ in the vertical slag samples.

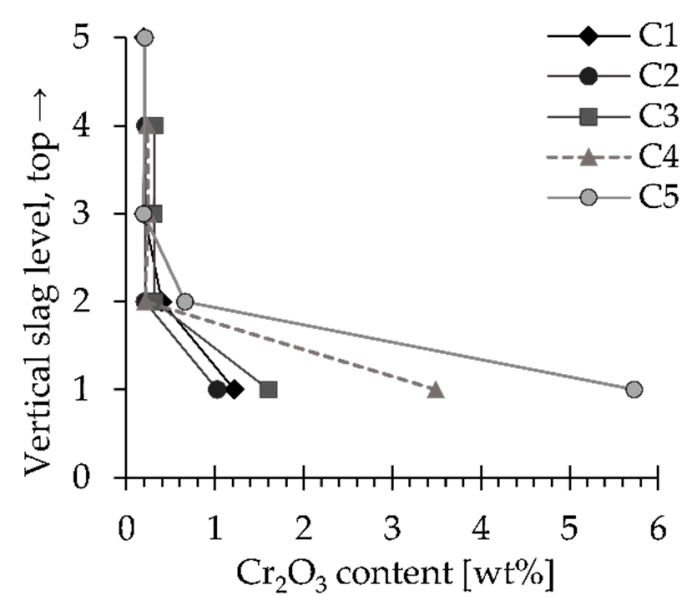

Figure 7. Chromium oxide content at all vertical slag levels at the settling end. Level 1 corresponds to the bottom-most layer in the slag bath and level 5/4 was the second-highest level in the slag bath.

The correlation between the bottom buildup, in the form of a chromium-rich spinel, and the slag copper content was observed in an earlier study, where copper droplets were attached to the spinel at the bottom of the slag layer [4]. The attachment of copper to a solid phase hinders the settling as the copper-solid entity has a lower density compared to the underlying copper phase, instead, it settles to the bottom slag layer where it accumulates. When the chromium content reaches above the chromium solubility in the slag chromium could precipitate as a spinel [24]. Spinels are possible solids in the slag layer, which increases the slag viscosity [23], and thus decreases the settling rate.

A drawback with the slag modification is the increased slag amount and cost of raw materials. However, if the slag modification does not affect the process in a negative 
way or the usage of the granulated slag, these disadvantages can be disregarded after the economic perspective is evaluated. The effect of the $\mathrm{CaO}$ modification on the slag properties influencing the settling in a slag system similar to the one in the present work $\left(\mathrm{Fe} / \mathrm{SiO}_{2}\right.$ ratio close to unity) is a task of significant importance. An investigation to find the optimum $\mathrm{CaO}$ content for decreased slag viscosity needs to be evaluated experimentally and can thereby be applied for enhanced settling rate and thus copper recovery.

\section{Conclusions}

Settling of matte and speiss in a reduced iron silicate slag was examined in an industrial trial in the electric settling furnace. The trial was conducted to determine the effect of the $\mathrm{CaO}$ slag modification on the final slag copper content and copper recovery between the settled copper phases and the slag phase. The results from the study indicate that the copper content in $\mathrm{CaO}$ modified slag decreases with increasing $\mathrm{CaO}$ content up to $11 \mathrm{wt} \%$, which indicates that $\mathrm{CaO}$ can be used as a slag modifier for increased copper recovery. However, the most significant decrease in the final slag copper content and increased copper recovery was when the reference batch with a $\mathrm{CaO}$ content of $3.1 \mathrm{wt} \%$ was compared with batch $\mathrm{C} 2$ with a $\mathrm{CaO}$ content of $7.2 \mathrm{wt} \%$. The results need to be confirmed in controlled laboratory experiments where the ingoing conditions-e.g., ingoing copper content, temperature, and settling time-are kept constant for all experiments.

Author Contributions: Conceptualization, J.I., T.V., A.L. and C.S.; Formal analysis, J.I. and T.V.; Investigation, J.I.; Methodology, J.I., T.V., A.L. and C.S.; Supervision, A.L., A.A. and C.S.; Visualization, J.I.; Writing-original draft, J.I.; Writing—review \& editing, J.I., T.V., A.L., A.A. and C.S. All authors have read and agreed to the published version of the manuscript.

Funding: The present work was financially supported by Boliden through Bolidenpaketet. The study is conducted within the context of $\mathrm{CAMM}^{2}$ (Center of Advanced Mining and Metallurgy) at Luleå University of Technology.

Institutional Review Board Statement: Not applicable.

Informed Consent Statement: Not applicable.

Data Availability Statement: Not applicable.

Conflicts of Interest: The authors declare no conflict of interest.

\section{References}

1. Coursol, P.; Valencia, N.C.; Mackey, P.; Bell, S.; Davis, B. Minimization of Copper Losses in Copper Smelting Slag During Electric Furnace Treatment. JOM 2012, 64, 1305-1313. [CrossRef]

2. Bellemans, I.; De Wilde, E.; Moelans, N.; Verbeken, K. Metal losses in pyrometallurgical operations-A review. Adv. Colloid Interface Sci. 2018, 255, 47-63. [CrossRef] [PubMed]

3. Lotfian, S.; Vikström, T.; Lennartsson, A.; Björkman, B.; Ahmed, H.; Samuelsson, C. Plastic-containing materials as alternative reductants for base metal production. Can. Metall. Q. 2019, 58:2, 164-176. [CrossRef]

4. Isaksson, J.; Vikström, T.; Lennartsson, A.; Samuelsson, C. Influence of Process Parameters on Copper Content in Reduced Iron Silicate Slag in a Settling Furnace. Metals 2021, 11, 992. [CrossRef]

5. Borell, M. Slag-A resource in the sustainable society. In Securing the Future, Proceedings of the International Conference on Mining and the Environment, Metals and Energy Recovery, Skelleftea, Sweden, 27 June-1 July 2005; SveMin: Skellefteå, Sweden, 2005; pp. 1-9.

6. Schlesinger, M.E.; King, M.J.; Sole, K.C.; Davenport, W.G. Extractive Metallurgy of Copper, 5th ed.; Elsevier Ltd.: Oxford, UK, 2011; ISBN 978-0-08-096789-9.

7. Shen, H.; Forssberg, E. An overview of recovery of metals from slags. Waste Manag. 2003, 23, 933-949. [CrossRef]

8. Utigard, T.A. Density of copper/nickel sulphide smelting and converting slags. Scand. J. Metall. 1994, $23,37-41$.

9. Mostaghel, S.; Samuelsson, C.; Björkman, B. Influence of alumina on mineralogy and environmental properties of zinc-copper smelting slags. Int. J. Miner. Metall. Mater. 2013, 20, 234-245. [CrossRef]

10. Mackey, P.J. The Physical Chemistry of Copper Smelting Slags-A Review. Can. Metall. Q. 1982, 21:3, 221-260. [CrossRef]

11. Starodub, K.; Kuminova, Y.; Dinsdale, A.; Cheverikin, V.; Filichkina, V.; Saynazarov, A.; Khvan, A.; Kondratiev, A. Experimental Investigation and Modeling of Copper Smelting Slags. Metall. Mater. Trans. B 2016, 47B, 2904-2918. [CrossRef]

12. Stokes, G.G. On the Effects of the Internal Friction of Fluids on the Motion of Pendulums. Trans. Camb. Philos. Soc. 1850, 9, 75-129. [CrossRef]

13. Kaiura, G.H.; Toguri, J.M.; Marchant, G. Viscosity of Fayalite-Based Slags. Can. Metall. Q. 1977, 16:1, 156-160. [CrossRef] 
14. Ducret, A.C.; Rankin, W.J. Liquidus temperatures and viscosities of $\mathrm{FeO}-\mathrm{Fe}_{2} \mathrm{O}_{3}-\mathrm{SiO}_{2}-\mathrm{CaO}-\mathrm{MgO}$ slags at compositions relevant to nickel matte smelting. Scand. J. Metall. 2002, 31, 59-67. [CrossRef]

15. Zhang, H.; Fu, L.; Qi, J.; Xuan, W. Physicochemical Properties of the Molten Iron-Rich Slags Related to the Copper Recovery. Metall. Mater. Trans. B 2019, 50B, 1852-1861. [CrossRef]

16. Yan, Z.; Reddy, R.G.; Lv, X.; Pang, Z.; Bai, C. Viscosity of Iron Oxide Aluminosilicate Melts. Metall. Mater. Trans. B 2019, 50B, 251-261. [CrossRef]

17. Selivanov, E.; Gulyaeva, R.; Istomin, S.; Belyaev, V.; Tyushnyakov, S.; Bykov, A. Viscosity and thermal properties of slag in the process of autogenous smelting of copper-zinc concentrates. Miner. Process. Extr. Metall. 2015, 124, 88-95. [CrossRef]

18. Mostaghel, S.; Matsushita, T.; Samuelsson, C.; Björkman, B.; Seetharaman, S. Influence of alumina on physical properties of an industrial zinc-copper smelting slag: Part 1-Viscosity. Miner. Process. Extr. Metall. 2013, 122, 42-48. [CrossRef]

19. Park, H.-S.; Park, S.S.; Sohn, I. The Viscous Behavior of FeOt-Al2O3-SiO2 Copper Smelting Slags. Metall. Mater. Trans. B 2011, 42B, 692-699. [CrossRef]

20. Huang, A.; Huo, Y.; Yang, J.; Gu, H.; Li, G. Computational Modeling and Prediction on Viscosity of Slags by Big Data Mining. Minerals 2020, 10, 257. [CrossRef]

21. Deng, L.; Wang, S.; Zhang, Z.; Li, Z.; Jia, R.; Yun, F.; Li, H.; Ma, Y.; Wang, W. The viscosity and conductivity of the molten glass and crystallization behavior of the glass ceramics derived from stainless steel slag. Mater. Chem. Phys. 2020, 251, 123159. [CrossRef]

22. Chen, M.; Raghunath, S.; Zhao, B. Viscosity measurements of SiO2-"FeO"-MgO system in equilibrium with metallic Fe. Metall. Mater. Trans. B 2014, 45B, 58-65. [CrossRef]

23. Zhou, S.; Wei, Y.; Shi, Y.; Li, B.; Wang, H. Characterization and Recovery of Copper from Converter Copper Slag via Smelting Separation. Metall. Mater. Trans. B 2018, 49B, 2458-2468. [CrossRef]

24. Sukhomlinov, D.; Avarmaa, K.; Virtanen, O.; Taskinen, P.; Jokilaakso, A. Slag-Copper Equilibria of Selected Trace Elements in Black Copper Smelting. Part I. Properties of the Slag and Chromium Solubility. Miner. Process. Extr. Metall. Rev. 2020, 41:1, 32-40. [CrossRef]

25. Tan, P. Modeling and control of copper loss in smelting slag. JOM 2011, 63, 51-57. [CrossRef]

26. Fagerlund, K.O.; Jalkanen, H. Microscale Simulation of Settler Processes in Copper Matte Smelting. Metall. Mater. Trans. B 2000, 31B, 439-451. [CrossRef]

27. Elliott, J.F.; Mouniert, M. Surface and Interfacial Tensions in Copper Matte-Slag Systems, $1200{ }^{\circ}$ C. Can. Metall. Q. 1982, 21, 415-428. [CrossRef]

28. Natsui, S.; Nashimoto, R.; Kumagai, T.; Kikuchi, T.; Suzuki, R.O. An SPH Study of Molten Matte-Slag Dispersion. Metall. Mater. Trans. B 2017, 48B, 1792-1806. [CrossRef]

29. Kim, H.G.; Sohn, H.Y. Effects of $\mathrm{CaO}, \mathrm{Al}_{2} \mathrm{O}_{3}$, and $\mathrm{MgO}$ Additions on the Copper Solubility, Ferric/Ferrous Ratio, and MinorElement Behavior of Iron-Silicate Slags. Metall. Mater. Trans. B 1998, 29B, 583-590. [CrossRef]

30. Holzheid, A.; Lodders, K. Solubility of copper in silicate as function of oxygen and sulfur fugacities, temperature, and silicate composition. Geochim. Cosmochim. Acta 2001, 65, 1933-1951. [CrossRef]

31. Shishin, D.; Jak, E.; Decterov, S.A. Thermodynamic Assessment of Slag-Matte-Metal Equilibria in the Cu-Fe-O-S-Si System. J. Phase Equilib. Diffus. 2018, 39, 456-475. [CrossRef]

32. Klaffenbach, E.; Mostaghel, S.; Guo, M.; Blanpain, B. Thermodynamic Analysis of Copper Smelting, Considering the Impact of Minor Elements Behavior on Slag Application Options and Cu Recovery. J. Sustain. Metall. 2021, 7, 664-683. [CrossRef] 